\title{
Faktor yang Berhubungan dengan Kadar COHb pada Petugas Parkir Plaza X Surabaya
}

Rizky Rahadian Wicaksono ${ }^{1}$

Email : rahadian.rizky85@gmail.com

1) Dosen S1 Program Studi Ilmu Lingkungan Fakultas Teknik Universitas Islam Lamongan

\begin{abstract}
Abstrak
Tujuan dari penelitian ini adalah untuk mempelajari pengaruh faktor risiko meliputi usia, jenis kelamin, masa kerja, posisi tubuh saat bekerja, kebiasaan merokok, golongan darah, status gizi, tingkat $\mathrm{Hb}$, untuk $\mathrm{COHb}$ tingkat darah pada petugas parkir di X Plaza Surabaya. Penelitian ini merupakan penelitian observasional analitik yang dilakukan cross sectional. Penelitian ini dilakukan pada April-Juni 2013. Data dikumpulkan pada minggu ke-2 Mei 2013. Jumlah sampel dalam penelitian ini menggunakan 30 orang yang bekerja sebagai petugas parkir X Plaza Surabaya dari 45 orang. Metode pengambilan sampel menggunakan simple random sampling dan mengidentifikasi darah $\mathrm{COHb}$ tingkat penggunaan wawancara langsung tentang umur, kehidupan, posisi tubuh bekerja sambil bekerja, kebiasaan merokok dan jenis darah. Dalam penelitian ini, pengukuran monoksida konsentrasi udara karbon di parkir plaza x dilakukan pada tiga titik sekitar area kerja petugas. Data dianalisis untuk korelasi COHb dengan usia, masa kerja, $\mathrm{Hb}$, digunakan korelasi person karena distribusi data adalah normal. Korelasi antara gender, kebiasaan merokok dan posisi tubuh saat bekerja dengan tingkat $\mathrm{COHb}$ darah yang digunakan sampel $\mathrm{T}$ dianalisis. Korelasi antara jenis darah dan kadar $\mathrm{COHb}$ darah dianalisis menggunakan analisis varians/ANOVA karena mereka memiliki 4 jenis. Status gizi dianalisis menggunakan Spearman korelasi. Hasil penelitian menunjukkan bahwa kadar karbon monoksida tertinggi ditemukan di sepeda motor yang 16,1 ppm. Standar mutu udara ambien berdasarkan PP Nomor 41 tahun 1999 adalah 10 ppm, jika kita dibandingkan dengan hasil kami menyimpulkan bahwa tingkat CO di parkir motor telah melampaui ambang batas. Berdasarkan hasil penelitian ini, disarankan untuk menyediakan lebih pembuangan lokal atau sistem pendingin udara di sekitar tempat kerja petugas parkir untuk mengurangi kadar $\mathrm{CO}$ yang dihasilkan oleh kendaraan. Juga, kami menyarankan kepada manajemen penanganan petugas parkir untuk memberikan vitamin $\mathrm{C}$ dan vitamin E sebagai antioksidan yang mengurangi racun dalam tubuh mereka dan memberikan fasilitas check up untuk kondisi kesehatan secara teratur.
\end{abstract}

Kata kunci: Tingkat Karbon Monoksida, Kadar COHb, Petugas Parkir

\section{PENDAHULUAN}

Udara sebagai komponen lingkungan yang penting dalam kehidupan perlu dipelihara dan dijaga kualitasnya sehingga dapat memberikan daya dukungan bagi mahluk hidup untuk hidup secara optimal. Udara merupakan media lingkungan yang merupakan kebutuhan dasar manusia perlu mendapatkan perhatian serius. Hal ini pula menjadi kebijakan pembangunan kesehatan Indonesia 2010 dimana program pengendalian pencemaran udara merupakan salah satu program unggulan (Depkes 2008).

Polusi udara adalah ancaman kesehatan lingkungan untuk anak dan merupakan faktor risiko untuk penyakit pernapasan baik akut atau kronik. Asap rokok terhadap lingkungan dan polutan luar ruangan tertentu diketahui sebagai faktor risiko infeksi pernapasan akut, polusi udara dalam ruangan dari bahan bakar organik merupakan penyumbang besar terhadap penyakit. Polusi udara di luar ruangan bertambah akibat konsenkuensi peningkatan pembakaran bahan fosil untuk transportasi, pembangkit listrik aktivitas manusia. Merupakan masalah serius di seluruh bagian dunia, terutama di kota besar negara-negara berkembang dan di perkiraan seperempat populasi dunia terpapar polutan udara yang tidak sehat (Anonim 2008).

Di udara, karbon monoksida (CO) terdapat dalam jumlah yang sangat sedikit, hanya sekitar 0,1 ppm. Di perkotaan dengan lalu lintas yang padat 
konsentrasi gas CO antara 10-15 ppm. Sudah sejak lama diketahui bahwa gas $\mathrm{CO}$ dalam jumlah banyak maupun rendah dapat menyebabkan gangguan kesehatan bahkan juga dapat menimbulkan kematian. Kadar $\mathrm{COHb}$ rendah yang sudah ditemukan contoh kasus harian Kompas sebagai berikut :

a) Empat orang tewas ditemukan di dalam mobil di jalan raya Kuningan-Cirebon. Berdasarkan hasil visum Tim Forensik RS Gunung Jati, ditemukannya racun pada saluran pernafasan korban berupa gas $\mathrm{CO}$ (Karbon Monoksida) akibat menghirup asap knalpot yang masuk ke dalam kendaraan. Asap knalpot dapat masuk ke dalam mobil karena adanya kebocoran pada knalpot dan bagian bawah body mobil (Oke zone 2007).

b) Selasa 11 Desember 2002 lalu, 19 karyawan pusat belanja Carrefour di Ratu Plaza, Jakarta, pingsan karena keracunan gas karbon monoksida. Ini insiden keempat sejak 2002. Para karyawan itu pingsan setelah listrik di gedung milik PT Ratu Sayang International itu mati dan penyejuk udara tak beroperasi (Oke zone 2007).

Mall adalah salah satu tempat hiburan, bersosialisasi serta melepas kepenatan serta bergaya lebih modern. Plaza X terletak disurabaya selatan ini adalah merupakan salah satu dari sekian banyak plaza di Kota Surabaya, di mana terdapat pengunjung dan pekerja di tempat tersebut. Berdasarkan studi pendahuluan awal dan wawancara yang telah dilakukan oleh peneliti terhadap pekerja parkir di plaza tersebut sebagian besar pekerja sering merasakan keluhan pandangan kabur, gangguan konsentrasi, dada sesak, pernafasan terganggu, mual serta pusing.

\section{Kerangka Konseptual Penelitian}

Salah satu pencemaran yang dihasilkan oleh mobil yaitu gas $\mathrm{CO}$, pemaparan Gas $\mathrm{CO}$ berpengaruh pada kadar CO dalam darah, efek CO terhadap kesehatan yaitu dengan pemaparan yang menerus akan dapat menimbulkan efek negatif.

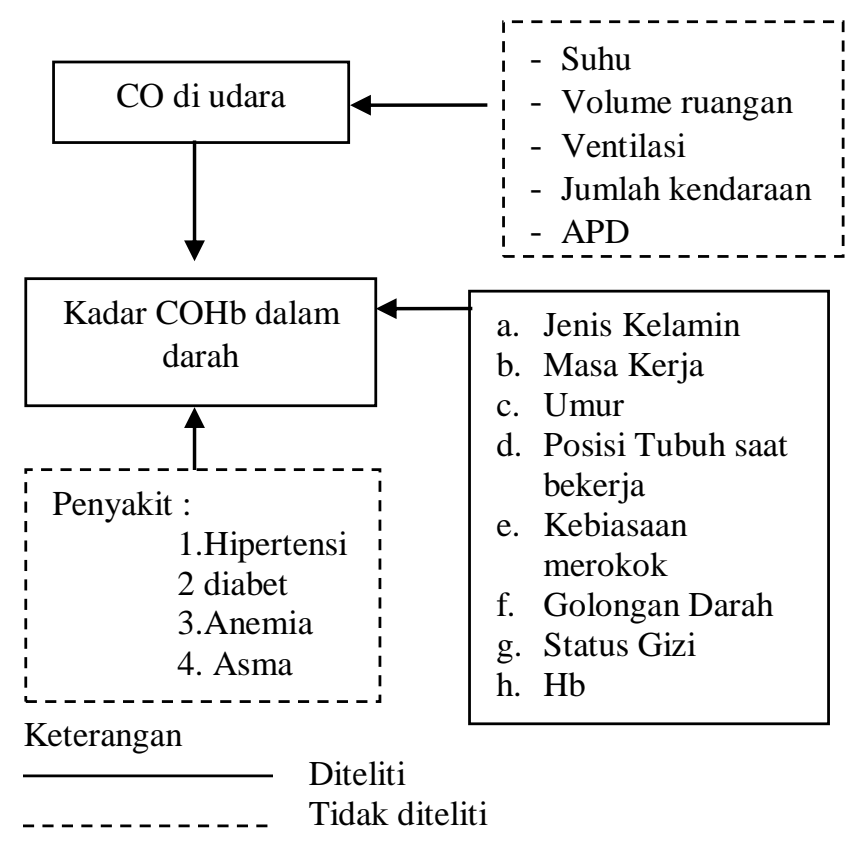

Gambar 1 Kerangka Konsep Penelitian.

Udara adalah faktor yang penting bagi seluruh kehidupan di dunia. Gas Karbon Monoksida (CO) adalah salah satu pencemar udara. Tempat parkir adalah salah satu sumber pencemaran udara terutama adalah CO yang terdapat parkir plaza harus menjadi perhatian, karena pengunjung dan pekerja dapat terpapar oleh gas buang atau rokok yang mengandung CO yang dapat menimbulkan efek negatif bagi kesehatan.

Kadar CO di udara ditentukan oleh Suhu, Ventilasi, APD, Jumlah kendaraan, luas ruangan. Pemaparan indoor dan outdoor contaminants dari CO dipengaruhi dari asap rokok, gas buang kendaraan bermotor. Apabila gas $\mathrm{CO}$ masuk ke dalam tubuh akan mengikat $\mathrm{Hb}$ dan kemudian membentuk ikatan $\mathrm{COHb}$ yang kuat. Kadar $\mathrm{COHb}$ dalam darah dipengaruhi beberapa faktor yaitu kebiasaan merokok, masa kerja dan umur, jenis kelamin, Golongan darah, Posisi saat kerja dan status gizi dan $\mathrm{Hb}$. Kadar $\mathrm{COHb}$ dalam darah dipengaruhi juga oleh hipertensi, diabet, anemia, asma

\section{Paparan CO di Tempat Kerja}

Berdasarkan Paparan $\mathrm{CO}$ di parkir plaza $\mathrm{x}$ surabaya pada 11 Mei 2013 antara pukul 11.00-12.00 WIB dengan menggunakan $\mathrm{CO}$ monitor Merk Krisbow KW 06292, didapatkan kadar rata-rata CO lingkungan di seluruh lokasi parkir plaza x sebesar 8,7 
$\pm 6,4$ ppm, dengan kadar tertinggi di bagian motor yaitu 16,1 ppm, sedangkan di bagian LG, P1, P2 masing-masing sebesar 4,8; 4,6; 1,8 ppm (Tabel 5.2). Jika dibandingkan dengan kadar $\mathrm{CO}$ yang diperkenankan untuk pekerja di dalam ruang (WHO,1994 ). Sebesar 9 ppm atau Baku Mutu kualitas udara Ambien (PP No 41 tahun 1999) yaitu 10 ppm maka kadar CO di parkir motor sudah melebihi ambang tersebut.

\section{METODOLOGI PENELITIAN}

Dapat dilihat dari jenisnya, penelitian ini termasuk penelitian lapangan yang bersifat Observasional Analitik. Dilihat dari pendekatan waktu, penelitian ini merupakan penelitian Cross Sectional, yaitu pengukuran paparan efek yang timbul dilakukan pada saat bersamaan.

\section{Tahap Penelitian}

Populasi petugas parkir plaza x Surabaya

Pengambilan data sebelum kerja yaitu kuisioner $\mathrm{COHb}, \mathrm{Hb}$, goldar

Pengambilam data diakhir jam kerja $\mathrm{COHb}$ darah

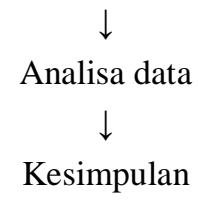

\section{HASIL DAN ANALISA DATA}

\section{Karakteristik Responden}

Berdasarkan data dari semua petugas parkir di 4 lantai yang berjumlah 30 orang, 73\% adalah laki laki dan dan mayoritas berumur kurang dari 40 tahun (23,7 $\pm 5,2$ tahun). Responden yang bekerja di lokasi motor sebesar $40 \%$ dan terbiasa bekerja dengan posisi berdiri sebesar $60 \%$. Responden yang mempunyai kebiasaan merokok sebesar $60 \%$ dan sebagian besar IMT responden berada dalam kategori normal (63,3\%). Responden mempunyai golongan darah terbanyak adalah $\mathrm{O}$ dan $\mathrm{B}$, dan sebagian dari mereka mengalami anemia dibandingkan dengan kadar $\mathrm{CO}$ yang diperkenankan untuk pekerja di dalam ruang (WHO, 1994 ). Sebesar 9 ppm atau Baku Mutu kualitas udara Ambien (PP No 41 tahun 1999) yaitu 10 ppm maka kadar CO di parkir motor sudah melebihi ambang tersebut.

Tabel 1 Karakteristik responden pekerja parkir plaza $\mathrm{x}$ Surabaya.

\begin{tabular}{|c|c|c|c|}
\hline Variabel & Kategori & Jumlah & $\%$ \\
\hline \multirow{2}{*}{$\begin{array}{l}\text { Jenis } \\
\text { Kelamin }\end{array}$} & Laki-laki & 22 & 73,3 \\
\hline & Perempuan & 8 & 26,7 \\
\hline \multirow[t]{2}{*}{ Umur } & $\leq 40$ Tahun & 27 & 90,0 \\
\hline & $>40$ Tahun & 3 & 10,0 \\
\hline \multirow[t]{2}{*}{ Masa Kerja } & $\leq 1$ Tahun & 12 & 40,0 \\
\hline & $>1$ Tahun & 18 & 60,0 \\
\hline \multirow{2}{*}{$\begin{array}{l}\text { Posisi } \\
\text { bekerja }\end{array}$} & Berdiri & 18 & 60,0 \\
\hline & Duduk & 12 & 40,0 \\
\hline \multirow{4}{*}{$\begin{array}{l}\text { Golongan } \\
\text { Darah }\end{array}$} & $\mathrm{O}$ & 11 & 36,7 \\
\hline & A & 5 & 16,7 \\
\hline & B & 12 & 40,0 \\
\hline & $\mathrm{AB}$ & 2 & 6,7 \\
\hline \multirow{2}{*}{$\begin{array}{l}\text { Kategori } \\
\mathrm{Hb}^{*}\end{array}$} & Anemia & 6 & 20,0 \\
\hline & $\begin{array}{l}\text { Tidak } \\
\text { anemia }\end{array}$ & 24 & 80,0 \\
\hline \multirow[t]{2}{*}{$\begin{array}{l}\text { Kebiasaan } \\
\text { merokok }\end{array}$} & $\mathrm{Ya}$ & 18 & 60,0 \\
\hline & Tidak & 12 & 40,0 \\
\hline \multirow{3}{*}{$\begin{array}{l}\text { Kategori } \\
\text { IMT }\end{array}$} & Kurus & 2 & 6,7 \\
\hline & Normal & 19 & 63,3 \\
\hline & Gemuk & 9 & 30,0 \\
\hline $\begin{array}{l}\text { *Kategori } \\
\text { gr/dl.dan Wa }\end{array}$ & $\begin{array}{l}\text { emia (Labkesda) } \\
\mathrm{a}: 12 \mathrm{gr} / \mathrm{dl}\end{array}$ & untuk & $a: 13$ \\
\hline
\end{tabular}

Tabel 2 Kadar CO lingkungan berdasarlokasi kerja pekerja parkir plaza x Surabaya tahun 2013.

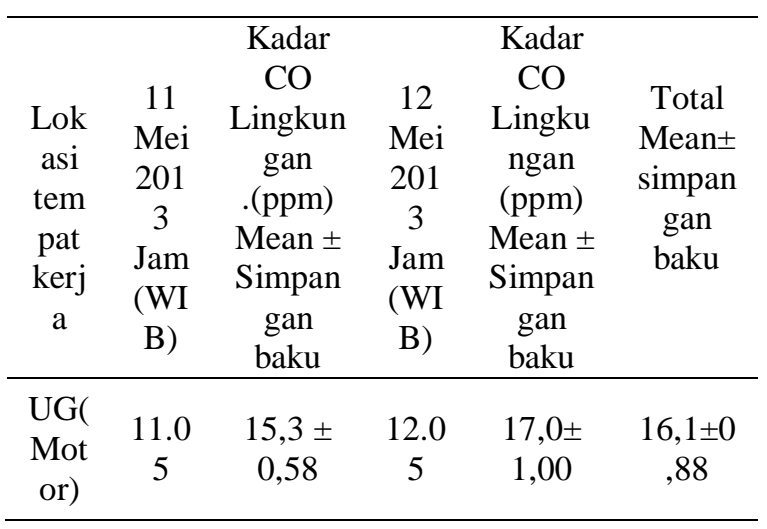




\begin{tabular}{cccccc}
\hline \multirow{2}{*}{ LG } & 11.1 & $6,0 \pm$ & 12.2 & $3,67 \pm$ & $4,8 \pm 1$, \\
& 5 & 1,00 & 0 & 0,58 & 23 \\
\hline \multirow{2}{*}{$\mathrm{P} 1$} & 11.3 & $6,0 \pm$ & 12.3 & $3,33 \pm$ & $4,6 \pm 1$ \\
& 5 & 1,00 & 5 & 0,58 & 47 \\
\hline \multirow{2}{*}{$\mathrm{P} 2$} & 11.5 & $1,3 \pm$ & 12.5 & $2,33 \pm$ & $1,8 \pm 0$, \\
& 0 & 0,58 & 0 & 0,58 & 55 \\
\hline
\end{tabular}

Nilai (p) Signifikan Anova :
$\begin{array}{lll}\text { (p) : } 0,038 & \text { (p) }: 0,022 & \text { (p) : } 0,001\end{array}$

NAB berdasarkan (WHO) kadar CO indoor adalah 9 ppm selama 8 jam/hari.

Keterangan :

UG : Parkir Motor terletak pada lantai dasar yang ventilasi hanya pada pintu masuk dan keluar

LG : Parkir Mobil dasar terletak di atas parkir motor dan terdapat pintu masuk plaza

P1 : parkir Mobil lantai 1 tidak ada sirkulasi udara

P2 : Parkir Mobil Lantai 2 ada sirkulasi udara alami

\section{Kadar CO dalam darah pekerja parkir plaza $\mathrm{x}$ Surabaya}

Kadar $\mathrm{CO}$ dalam darah (COHb) pekerja yang diukur sebelum bekerja adalah $8,7 \pm 1,8 \%$ dengan kadar tertinggi didapatkan pada pekerja yang berada di

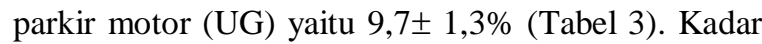
$\mathrm{COHb}$ sebelum bekerja diukur untuk mengetahui total paparan terdahulu termasuk kadar $\mathrm{CO}$ yang diproduksi dalam tubuh sebagai akibat dari proses katabolisme hemoglobin (Endogenous COHb). Referensi $\mathrm{COHb}$ pada bukan perokok adalah 0,5-0,8\% . Jika dibandingkan dengan referensi untuk perokok (3$10 \%$ ), kadar $\mathrm{COHb}$ pekerja tersebut melebihi referensi (Siswanto 1994).

Setelah selesai bekerja kadar $\mathrm{COHb}$ pekerja menjadi $9,0 \pm 1,9 \%$ atau meningkat $0,3 \%$. $\mathrm{COHb}$ sebelum dan $\mathrm{COHb}$ sesudah bekerja diukur untuk mengetahui efek akut paparan $\mathrm{CO}$ lingkungan saat penelitian (COHb sesudah) dengan mempertimbangkan paparan sebelumnya $(\mathrm{COHb}$ sebelum) sehingga peningkatan $\mathrm{COHb}$ dapat dipertimbangkan sebagai hasil paparan $\mathrm{CO}$ lingkungan saat penelitian saja.

Setelah dilakukan uji paired $t$ test, peningkatan $\mathrm{COHb}$ tersebut bermakna secara statistik $(\mathrm{p}<0,001)$. Pekerja yang berada di parkir motor (UG) baik sebelum, sesudah bekerja maupun peningkatan $\mathrm{COHb}$ setelah bekerja menunjukkan kadar $\mathrm{COHb}$ tertinggi dibanding dengan kadar $\mathrm{COHb}$ pekerja di lokasi parkir yang lain (Uji Anova dilanjutkan post Hoc test; $p=0,038 ; p=0,022 ; p=0,01$ ).

Tabel 3 Rerata kadar $\mathrm{COHb}$ sebelum kerja dan $\mathrm{COHb}$ sesudah kerja Berdasar lokasi kerja.

\begin{tabular}{|c|c|c|c|c|c|}
\hline Variabel & $\begin{array}{l}\text { Korelas } \\
\quad \mathrm{i}\end{array}$ & & $\begin{array}{c}\mathrm{COH} \\
\mathrm{b} \\
\text { sebel } \\
\text { um }\end{array}$ & $\begin{array}{c}\mathrm{COH} \\
\text { b } \\
\text { sesud } \\
\text { ah }\end{array}$ & $\begin{array}{c}\text { Selisi } \\
\mathrm{h} \\
\mathrm{COH} \\
\mathrm{b}\end{array}$ \\
\hline $\begin{array}{c}\text { Kadar } \\
\text { CO }\end{array}$ & $\begin{array}{l}\text { Spearm } \\
\text { an's }\end{array}$ & $\mathrm{r}_{\mathrm{s}}$ & 0,433 & 0,441 & 0,683 \\
\hline $\begin{array}{c}\text { lingkung } \\
\text { an }\end{array}$ & rho & $\mathrm{P}$ & $\begin{array}{c}0,017 \\
*\end{array}$ & $\begin{array}{c}0,015 \\
*\end{array}$ & $\begin{array}{c}0,000 \\
*\end{array}$ \\
\hline
\end{tabular}

Faktor yang ada hubungannya dengan kadar COHb dalam darah pekerja parkir plaza $x$

1. Hubungan antara $\mathrm{CO}$ Lingkungan dengan $\mathrm{COHb}$

Dari Tabel 4 diketahui bahwa terdapat korelasi yang signifikan antara kadar CO lingkungan dengan kadar $\mathrm{COHb}$ sebelum, sesudah bekerja dan selisih COHb $(p=0,017 ; p=0,015 ; p<0,001)$. Hal tersebut menunjukkan bahwa peningkatan $\mathrm{COHb}$ adalah akibat dari paparan $\mathrm{CO}$ lingkungan kerja.

Tabel 4 Hubungan antara kadar CO lingkungan dengan $\mathrm{COHb}$ sebelum, sesudah kerja dan selisih.

\begin{tabular}{ccccc}
\hline Lokasi & Jml & $\begin{array}{c}\text { COHb } \\
\text { Sebelum } \\
\text { Mean } \pm \\
\text { SD }\end{array}$ & $\begin{array}{c}\text { COHb } \\
\text { Sesudah } \\
\text { Mean } \pm \\
\text { SD }\end{array}$ & $\begin{array}{c}\text { COHb } \\
\text { Selisih } \\
\text { Mean } \pm \\
\text { SD }\end{array}$ \\
\hline Motor & \multirow{2}{*}{12} & $\begin{array}{c}9,654 \pm \\
1,255\end{array}$ & $\begin{array}{c}10,053 \pm \\
1,369\end{array}$ & $\begin{array}{c}0,398 \pm \\
0,189\end{array}$ \\
\hline \multirow{2}{*}{ LG } & \multirow{2}{*}{6} & $\begin{array}{c}8,995 \pm \\
1,513\end{array}$ & $\begin{array}{c}9,242 \pm \\
1,536\end{array}$ & $\begin{array}{c}0,247 \pm \\
0,148\end{array}$ \\
\hline \multirow{2}{*}{ P1 } & \multirow{2}{*}{6} & $\begin{array}{c}7,568 \pm \\
1,433\end{array}$ & $\begin{array}{c}7,728 \pm \\
1,471\end{array}$ & $\begin{array}{c}0,160 \pm \\
0,103\end{array}$ \\
\hline \multirow{2}{*}{ P2 } & \multirow{2}{*}{6} & $\begin{array}{c}7,728 \pm \\
2,339\end{array}$ & $\begin{array}{c}7,825 \pm \\
2,407\end{array}$ & $\begin{array}{c}0,097 \pm \\
0,090\end{array}$ \\
\hline \multirow{2}{*}{ Total } & \multirow{2}{*}{30} & $\begin{array}{c}8,720 \pm \\
1,773\end{array}$ & $\begin{array}{c}8,980 \pm \\
1,891\end{array}$ & $\begin{array}{c}0,260 \pm \\
0,190\end{array}$ \\
\hline
\end{tabular}

Keterangan : Korelasi signifikan jika p : $<0,05$

2. Hubungan antara jenis kelamin dengan $\mathrm{COHb}$.

Berdasarkan Tabel 5 dapat diketahui kadar $\mathrm{COHb}$ sebelum bekerja, sesudah bekerja dan selisih 
$\mathrm{COHb}$ pada laki laki lebih tinggi dibanding dengan pada perempuan (uji t 2 sampel bebas; $\mathrm{p}<0.001$; $\mathrm{p}<0.001 ; \mathrm{p}=0.029$ ).

Tabel 5 Hasil uji komparasi $\mathrm{COHb}$ sebelu dan $\mathrm{COHb}$ sesudah kerja berdasar jenis kelamin.

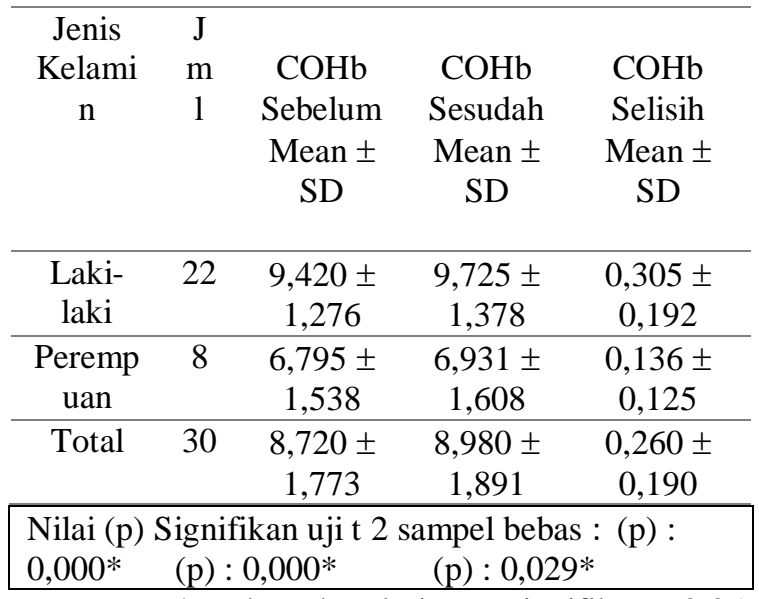

Keterangan : * terdapat korelasi yang signifikan. $<0,05$

3. Hubungan antara Umur dengan Kadar $\mathrm{COHb}$.

Berdasarkan Tabel 6 diketahui bahwa pada petugas parkir yang rata-rata berumur 25,3 tahun menunjukkan bahwa tidak ada hubungan antara umur dengan kadar $\mathrm{COHb}(\mathrm{p}>0,05)$.

Tabel 6 Korelasi antara umur dengan $\mathrm{COHb}$ sebelum, $\mathrm{COHb}$ sesudah kerja dan selisih $\mathrm{COHb}$.

\begin{tabular}{|c|c|c|c|c|c|}
\hline Variabe & Korelasi & & $\begin{array}{l}\mathrm{COHb} \\
\text { sebelum }\end{array}$ & $\begin{array}{l}\mathrm{COHb} \\
\text { sesudah }\end{array}$ & $\begin{array}{l}\text { Selisih } \\
\mathrm{COHb}\end{array}$ \\
\hline \multirow{3}{*}{$\begin{array}{l}\text { Umur } \\
\text { (th) }\end{array}$} & Pearson & $\mathrm{r}$ & 0,135 & 0,118 & $-0,080$ \\
\hline & & $\mathrm{p}$ & $0,478^{*}$ & $0,534^{*}$ & $0,673^{*}$ \\
\hline & & jml & 30 & 30 & 30 \\
\hline
\end{tabular}

Keterangan : * terdapat korelasi yang signifikan, $\mathrm{r}$ :

Koefisien korelasi, p : signifikan (jika p < 0,05

4. Hubungan antara masa kerja dengan kadar $\mathrm{COHb}$

Pekerja yang masa kerjanya rata-rata 2,2 tahun (range $1-7$ tahun) dalam penelitian ini menunjukkan tidak ada hubungan antara masa kerja dengan kadar $\mathrm{COHb}$ sebelum, sesudah bekerja dan selisih $\mathrm{COHb}$ $(\mathrm{p}>0,05)$.

Tabel 7 Hasil uji korelasi antara masa kerja dengan $\mathrm{COHb}$ sebelum, $\mathrm{COHb}$ sesudah dan selisih $\mathrm{COHb}$.

\begin{tabular}{lccccc}
\hline Variabel & Korelasi & & $\begin{array}{c}\mathrm{COHb} \\
\text { sebelum }\end{array}$ & $\begin{array}{c}\mathrm{COHb} \\
\text { sesudah }\end{array}$ & $\begin{array}{c}\text { Selisih } \\
\mathrm{COHb}\end{array}$ \\
\hline Masa & Spearman & $\mathrm{r}_{\mathrm{s}}$ & 0,053 & 0,041 & 0,227 \\
\cline { 3 - 6 } Kerja & 's rho & $\mathrm{p}$ & $0,781^{*}$ & $0,829^{*}$ & $0,227^{*}$ \\
\cline { 3 - 6 } & & $\mathrm{n}$ & 30 & 30 & 30 \\
\hline
\end{tabular}

Keterangan : $r_{\mathrm{s}}$ : koefisien korelasi. Korelasi signifikan jika $\mathrm{p}<0,05$.

5. Hubungan antara kadar $\mathrm{Hb}$ dengan kadar $\mathrm{COHb}$.

Uji korelasi Pearson menunjukkan adanya hubungan antara kadar $\mathrm{Hb}$ pekerja dengan kadar $\mathrm{COHb}$ dalam darah $(\mathrm{p}<0,001 ; \mathrm{p}<0,001 ; \mathrm{p}=0.014)$.

Tabel 8 Hasil uji korelasi antara kadar $\mathrm{Hb}$ dengan $\mathrm{COHb}$ sebelum, $\mathrm{COHb}$ sesudah dan selisih $\mathrm{COHb}$

\begin{tabular}{|c|c|c|c|c|c|}
\hline Variabel & $\begin{array}{c}\text { Korel } \\
\text { asi }\end{array}$ & & \begin{tabular}{|c|}
$\begin{array}{c}\mathrm{COHb} \\
\text { sebelum }\end{array}$ \\
\end{tabular} & $\begin{array}{c}\mathrm{COHb} \\
\text { sesudah }\end{array}$ & $\begin{array}{l}\text { Selisih } \\
\mathrm{COHb}\end{array}$ \\
\hline \multirow[t]{3}{*}{ Kadar $\mathrm{Hb}$} & \multirow{3}{*}{$\begin{array}{c}\text { Pears } \\
\text { on }\end{array}$} & $\mathrm{r}$ & 0,640 & 0,644 & 0,443 \\
\hline & & $\mathrm{p}$ & $0,000^{*}$ & $0,000^{*}$ & $0,014^{*}$ \\
\hline & & $\mathrm{n}$ & 30 & 30 & 30 \\
\hline
\end{tabular}

Keterangan : $r$ : koefisien korelasi. Korelasi signifikan jika $\mathrm{p}<0,05$.

6. Hubungan antara Posisi tubuh saat bekerja dengan kadar $\mathrm{COHb}$.

Berat jenis CO $(0,97)$ lebih rendah dari udara $(1,00)$ maka peneliti menganalisis apakah kebiasaan posisi bekerja (duduk atau berdiri) berhubungan dengan kadar $\mathrm{COHb}$. Hasil uji komparasi menunjukkan bahwa tidak ada beda kadar $\mathrm{COHb}$ antara pekerja yang melakukan pekerjaan dengan berdiri dengan yang duduk $(\mathrm{p}>0,05)$.

Tabel 9 Hasil uji komparasi $\mathrm{COHb}$ sebelum dan $\mathrm{COHb}$ sesudah berdasar posisi tubuh saat bekerja.

\begin{tabular}{ccccc}
\hline $\begin{array}{c}\text { Posisi } \\
\text { tubuh } \\
\text { saat } \\
\text { bekerj } \\
\text { a }\end{array}$ & Jml & $\begin{array}{c}\text { COHb } \\
\text { Sebelum } \\
\text { Mean } \pm \text { SD }\end{array}$ & $\begin{array}{c}\text { COHb } \\
\text { Sesudah } \\
\text { Mean } \pm \text { SD }\end{array}$ & $\begin{array}{c}\text { COHb } \\
\text { Selisih } \\
\text { Mean } \pm \text { SD }\end{array}$ \\
\hline $\begin{array}{c}\text { Berdi } \\
\text { ri }\end{array}$ & 18 & $8,817 \pm 2,027$ & $9,083 \pm 2,138$ & $0,266 \pm 0,193$ \\
\hline $\begin{array}{c}\text { Dudu } \\
\text { k }\end{array}$ & 12 & $8,574 \pm 1,379$ & $8,826 \pm 1,526$ & $0,252 \pm 0,194$ \\
\hline Total & 30 & $8,720 \pm 1,773$ & $8,980 \pm 1,891$ & $0,260 \pm 0,190$ \\
\hline
\end{tabular}




Nilai (p) Signifikan Anova :
\begin{tabular}{lll} 
(p) $: 0,533$ & (p) $: 0,510$ & (p) : \\
0,273 & & \\
\hline
\end{tabular}

Uji beda signifikan jika $\mathrm{p}<0,05$.

7. Hubungan antara kebiasaan merokok dengan kadar $\mathrm{COHb}$.

Setiap kepulan asap rokok mengandung $\mathrm{CO}$ sebanyak 700-800 ppm (Siswanto, 1994), maka perokok akan terpapar dengan CO tambahan dari asap rokok selain CO dari lingkungan kerja, sehingga peneliti menganalisis apakah kebiasaan merokok ada hubungannya dengan kadar $\mathrm{COHb}$ pekerja. Hasil uji t 2 sampel bebas menunjukkan bahwa kadar $\mathrm{COHb}$ perokok lebih tinggi secara signifikan baik $\mathrm{COHb}$ sebelum, sesudah, selisih $\mathrm{COHb}$, dibanding dengan pekerja yang bukan perokok $(\mathrm{p}=0,002 ; \mathrm{p}=0,001$; $\mathrm{p}=0,035$ ).

Tabel 10 Perbedaan antara $\mathrm{COHb}$ berdasar kebiasaan merokok.

\begin{tabular}{|c|c|c|c|c|}
\hline $\begin{array}{l}\text { Go } \\
\text { lon } \\
\text { gan } \\
\text { Da } \\
\text { rah }\end{array}$ & $\begin{array}{l}\mathrm{j} \\
\mathrm{m} \\
\mathrm{l}\end{array}$ & $\begin{array}{c}\mathrm{COHb} \\
\text { Sebelum } \\
\text { Mean } \pm \text { SD }\end{array}$ & $\begin{array}{c}\mathrm{COHb} \\
\text { Sesudah } \\
\text { Mean } \pm \\
\text { SD }\end{array}$ & $\begin{array}{c}\text { COHb } \\
\text { Selisih } \\
\text { Mean } \pm \text { SD }\end{array}$ \\
\hline $\mathrm{A}$ & 5 & $\begin{array}{c}9,334 \pm \\
1,750\end{array}$ & $\begin{array}{c}9,578 \pm \\
1,734\end{array}$ & $\begin{array}{c}0,244 \pm \\
0,048\end{array}$ \\
\hline B & $\begin{array}{l}1 \\
2\end{array}$ & $\begin{array}{c}8,404 \pm \\
1,719\end{array}$ & $\begin{array}{c}8,623 \pm \\
1,863\end{array}$ & $\begin{array}{c}0,219 \pm \\
0,202\end{array}$ \\
\hline $\mathrm{AB}$ & 2 & $\begin{array}{c}7,455 \pm \\
1,747 \\
\end{array}$ & $\begin{array}{c}7,590 \pm \\
1,895\end{array}$ & $\begin{array}{c}0,135 \pm \\
0,148\end{array}$ \\
\hline $\mathrm{O}$ & $\begin{array}{l}1 \\
1\end{array}$ & $\begin{array}{c}9,015 \pm \\
1,901\end{array}$ & $\begin{array}{c}9,350 \pm \\
2,033\end{array}$ & $\begin{array}{c}0,335 \pm \\
0,214\end{array}$ \\
\hline $\begin{array}{l}\text { Tot } \\
\text { al }\end{array}$ & $\begin{array}{l}3 \\
0\end{array}$ & $\begin{array}{c}8,720 \pm \\
1,773\end{array}$ & $\begin{array}{c}8,980 \pm \\
1,891\end{array}$ & $\begin{array}{c}0,260 \pm \\
0,190\end{array}$ \\
\hline
\end{tabular}

Nilai (p) Signifikan Anova :

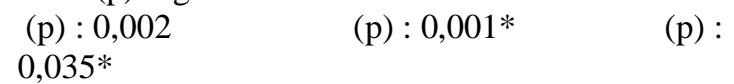

Keterangan : uji beda signifikan jika $\mathrm{p}<0,05$.

8. Hubungan antara Golongan darag dengan Kadar $\mathrm{COHb}$.

Supaya dapat mengetahui apakah ada perbedaan kadar $\mathrm{COHb}$ berdasar perbedaan golongan darah, maka peneliti menganalisis dengan menggunakan uji Anova. Tabel 11 menunjukkan bahwa tidak ada beda kadar $\mathrm{COHb}$ pada pekerja dengan golongan darah $\mathrm{A}, \mathrm{B}, \mathrm{AB}, \mathrm{O}(\mathrm{p}>0,05)$ baik kadar $\mathrm{COHb}$ sebelum, sesudah dan selisih $\mathrm{HbCO}$.

Tabel 11 Hasil uji komparasi $\mathrm{COHb}$ sebelum dan $\mathrm{COHb}$ sesudah berdasar golongan darah.

\begin{tabular}{|c|c|c|c|c|}
\hline $\begin{array}{c}\text { Kebia } \\
\text { saan } \\
\text { Mero } \\
\text { kok }\end{array}$ & $\mathrm{Jml}$ & $\begin{array}{c}\mathrm{COHb} \\
\text { Sebelu } \\
\mathrm{m} \\
\text { Mean } \pm \\
\mathrm{SD}\end{array}$ & $\begin{array}{c}\mathrm{COHb} \\
\text { Sesudah } \\
\text { Mean } \pm \\
\text { SD }\end{array}$ & $\begin{array}{c}\text { COHb } \\
\text { Selisih } \\
\text { Mean } \pm \\
\text { SD }\end{array}$ \\
\hline $\mathrm{Ya}$ & 18 & $\begin{array}{c}9,503 \pm \\
1,331\end{array}$ & $\begin{array}{c}9,822 \pm \\
1,426\end{array}$ & $\begin{array}{c}0,319 \pm \\
0,198\end{array}$ \\
\hline Tidak & 12 & $\begin{array}{c}7,545 \pm \\
1,744\end{array}$ & $\begin{array}{c}7,717 \pm \\
1,842\end{array}$ & $\begin{array}{c}0,172 \pm \\
0,143\end{array}$ \\
\hline Total & 30 & $\begin{array}{c}8,720 \pm \\
1,773\end{array}$ & $\begin{array}{c}8,980 \pm \\
1,891\end{array}$ & $\begin{array}{c}0,260 \pm \\
0,190\end{array}$ \\
\hline
\end{tabular}

Keterangan : uji beda signifikan jika $\mathrm{p}<0,05$.

9. Hubungan antara Indeks Masa Tubuh (IMT) dengan Kadar COHb.

Hasil uji statistic Anova menunjukkan bahwa tidak ada beda kadar $\mathrm{COHb}$ antara pekerja dengan indeks masa tubuh (IMT) kurus, normal dan gemuk, baik $\mathrm{COHb}$ sebelum, sesudah maupun selisih $\mathrm{COHb}$ $(\mathrm{p}>0,05)$.

Tabel 12 Hasil uji COHb sebelum dan HbCO sesudah $\mathrm{COHb}$ berdasar kategori IMT.

\begin{tabular}{ccccc}
\hline $\begin{array}{c}\text { Kategori } \\
\text { IMT }\end{array}$ & jml & $\begin{array}{c}\text { COHb } \\
\text { Sebelum } \\
\text { Mean } \pm \\
\text { SD }\end{array}$ & $\begin{array}{c}\text { COHb } \\
\text { Sesudah } \\
\text { Mean } \pm \\
\text { SD }\end{array}$ & $\begin{array}{c}\text { COHb } \\
\text { Selisih } \\
\text { Mean } \pm \\
\text { SD }\end{array}$ \\
\hline Kurus & 2 & $\begin{array}{c}10,090 \pm \\
1,032\end{array}$ & $\begin{array}{c}10,465 \pm \\
0,870\end{array}$ & $\begin{array}{c}0,375 \pm \\
0,163\end{array}$ \\
\hline Normal & 19 & $\begin{array}{c}8,384 \pm \\
1,979\end{array}$ & $\begin{array}{c}8,596 \pm \\
2,106\end{array}$ & $\begin{array}{c}0,212 \pm \\
0,179\end{array}$ \\
\hline Gemuk & 9 & $\begin{array}{c}9,124 \pm \\
1,237\end{array}$ & $\begin{array}{c}9,460 \pm \\
1,321\end{array}$ & $\begin{array}{c}0,336 \pm \\
0,201\end{array}$ \\
\hline Total & 30 & $\begin{array}{c}8,720 \pm \\
1,773\end{array}$ & $\begin{array}{c}8,980 \pm \\
1,891\end{array}$ & $\begin{array}{c}0,260 \pm \\
0,190\end{array}$ \\
\hline
\end{tabular}

Nilai (p) Signifikan Anova :
(p) : 0,321
(p) : 0,282
(p) : 0,190

Keterangan : * terdapat korelasi yang signifikan 


\section{PEMBAHASAN}

\section{Karakteristik Responden}

Berdasarkan semua petugas parkir di 4 lantai yang berjumlah 30 orang, $73 \%$ adalah laki laki dan dan mayoritas berumur kurang dari 40 tahun $(23,7 \pm 5,2$ tahun). Responden yang bekerja di lokasi motor sebesar 40\% dan terbiasa bekerja dengan posisi berdiri sebesar $60 \%$. Responden yang mempunyai kebiasaan merokok sebesar $60 \%$ dan sebagian besar IMT responden berada dalam kategori normal $(63,3 \%)$. Responden mempunyai golongan darah terbanyak adalah $\mathrm{O}$ dan $\mathrm{B}$, dan sebagian dari mereka mengalami anemia (20\%).

\section{Paparan kadar CO udara ditempat kerja}

Udara dimana di dalamnya terkandung sejumlah oksigen merupakan Komponen ensensial bagi kehidupan, baik manusia maupun mahluk hidup lainya. Udara dikatakan normal dan dapat mendukung kehidupan manusia apabila tidak terjadi penambahan gas lain yang menimbulkan gangguan serta perubahan komposisi udara, maka dikatakan udara sudah tercemar atau terpolusi. Akibat aktivitas perubahan manusia, udara sering kali menurun kualitasnya. Akibat aktivitas ini dapat berupa perubahan sifat-sifat fisik maupun sifat-sifat kimiawi. Perubahan kimiawi dapat berupa pengurangan maupun penambahan salah satu komponen kimia yang terkandung dalam udara. Kondisi seperti itu lazim disebut dengan pencemaran polusi udara (Anonim 2008)

Penelitian ini cara pengambilan sampel udara ditempat kerja menggunakan pengambilan sampel lingkungan kerja (area sampling) Pengambilan sampel udara lingkungan tempat kerja yang dilakukan dengan cara menempatkan alat pengambilan sampel udara pada suatu tempat tertentu dimana tenaga kerja melakukan pekerjaannya. pengukurannya dilakukan pada jam jam ramainya pengunjung dengan pertimbangan pada jam-jam terebut mulai ramai dan dipadati para Shopping holic dan diadakan event, promo.

Pengukuran $\mathrm{CO}$ udara didapatkan kadar ratarata $\mathrm{CO}$ lingkungan di seluruh lokasi parkir plaza $\mathrm{x}$ sebesar 8,7 $\pm 6,4 \mathrm{ppm}$, dengan kadar tertinggi di bagian motor yaitu $16,1 \mathrm{ppm}$, sedangkan di bagian LG, P1, P2 masing-masing sebesar 4,8, 4,6, 1,8 ppm, Jika dibandingkan dengan kadar $\mathrm{CO}$ yang diperkenankan untuk pekerja di dalam ruang (WHO, ) sebesar 9 ppm atau Baku Mutu kualitas udara Ambien (PP No 41 tahun 1999) yaitu 10 ppm maka kadar CO di parkir motor sudah melebihi ambang tersebut Hasil pembahasan ini disimpulkan sebagai berikut bahwa parkir motor kadar CO lebih tinggi dari pada mobil dengan jumlah kendaraan 576 motor dengan ketinggian atap hanya 2,8 meter dan tidak ada local exhaust fan dibandingkan dengan P2 kadar CO lebih rendah dengan jumlah kendaraan 164 kendaraan dengan ruang terdapat sirkulasi udara alami dan atap lebih tinggi sehingga mengencerkan gas CO. Konsentrasi CO di suatu ruang akan naik bila diruangan itu terdapat orang merokok. Orang yang merokok akan megeluarkan asap rokok yang mengandung gas $\mathrm{CO}$ dengan konsentrasi lebih dari 20.000 ppm yang kemudian menjadi encer sekitar 400-5000 ketika dihembuskan ke udara akhirnya terjadi pengenceran konsentrasi CO (Saputra 2009).

Terdapat perbedaan kadar $\mathrm{CO}$ udara di luar ruangan dengan kadar $\mathrm{CO}$ udara dalam ruangan mengingat kontruksi lahan plaza $\mathrm{x}$ surabaya mirip indoor artinya pemaparan gas $\mathrm{CO}$ lebih besar dari pada kadar CO diluar ruangan (outdoor contaminants) lebih banyak dipengaruhi oleh gas buang kendaraan bermotor dan beberapa proses industri. Sedangkan dalam ruangan (indoor contaminants ) dipengaruhi oleh asap rokok pada orang yang merokok dan gas buang kendaraan bermotor. Tingkat pemaparan polusi udara indoor (ruang tertutup) lebih besar jika dibandingkan dengan pemaparan polusi udara outdoor. (Anonim 2009).

\section{Kadar CO dalam darah Pekerja Parkir plaza $x$ Surabaya}

Berdasarkan hasil Kadar $\mathrm{CO}$ dalam darah $(\mathrm{COHb})$ pekerja yang diukur sebelum bekerja adalah $8,7 \pm 1,8 \%$. Setelah selesai bekerja kadar $\mathrm{COHb}$ pekerja menjadi $9,0 \pm 1,9 \%$ atau meningkat $0,3 \%$. dengan kadar tertinggi didapatkan pada pekerja yang berada di parkir motor (UG) yaitu $9,7 \pm 1,3 \%$. Dengan tingginya kadar $\mathrm{COHb}$ dalam darah petugas parkir plaza $\mathrm{x}$ merupakan hal penting yang wajib mendapat perhatian serius artinya terjadi paparan gas $\mathrm{CO}$ pada kendaraan bermotor ditambah dari asap rokok.

Menurut Fardiaz (1992), Faktor penting yang menentukan pengaruh $\mathrm{CO}$ terhadap tubuh manusia adalah kadar $\mathrm{COHb}$, dimana semakin tinggi prosentasenya hemoglobin yang terikat dalam bentuk $\mathrm{COHb}$, maka semakin parah pengaruhnya terhadap kesehatan manusia. Untuk kadar $\mathrm{COHb}$ dalam darah $<1 \%$ tidak menimbulkan pengaruh terhadap kesehatan,untuk konsentrasi (1-2\%) penampilan tidak normal, sedangkan konsentrasi (2-5\%) mampu 
memberikan pengaruh terhadap sistem saraf sentral reaksi panca indra tidak normal, dan benda terlihat agak kabur. Untuk konsentrasi (5-10\%) menimbulkan perubahan fungsi jantung, sedangkan untuk konsentrasi (10-80\%) menimbulkan kepala pening, mual, mata berkunang, pingsan, sukar bernafas serta kematian. Ada beberapa kemungkinan kadar petugas parkir kadar CO di dalam darah melebihi batas normal yang merupakan faktor lain yang mempengaruhi adalah :

\section{Jarak tinggal}

Jarak tinggal subjek penelitian dengan tempat kerja, disini maksudnya semakin jauh subjek penelitian dengan tempat kerja, semakin besar berisiko subjek penelitian terpapar CO selama di perjalanan Waktu berangkat kerja. Misalnya, pekerja yang jarak tempat tinggalnya jauh dari tempat kerja waktu kontak dengan CO lebih lama dan kadar CO di udara yang terlewati lebih bervariasi.

\section{Transportasi yang digunakan}

Pekerja yang mengendarai sepeda motor lebih mudah terpapar polutan $\mathrm{CO}$ yang berada di udara, bila dibandingkan dengan pekerja yang mengendarai sepeda motor lebih cenderung mempunai kadar $\mathrm{COHb}$ dalam darah yang tinggi dari pekerja yang mengendarai mobil. Kondisi sepeda motor yang terbuka lebih memudahkan pemaparan pada pengendaranya selain kemungkinan pekerja yang tidak memakai masker (alat pelindung hidung) sewaktu mengendarai sepeda motor.

Karbon Monoksida yang dihasilkan dari gas buang dari kendaraan bermotor yang memakai bahan bakar bensin kadar CO nya sebesar 1\%-7\% pada kendaraan bermotor dengan bahan bakar solar sebesar $0.2 \%-4 \%$ (Siswanto 2008).

\section{Beban Kerja}

Beban Kerja yang dialami masing-masing subyek penelitian juga tidak sama antara yang duduk dengan berjalan Karboksihemoglobin darah dapat ditentukan dengan mudah di dalam sampel darah vena, yang harus dikumpulkan dalam sebuah wadah tertutup yang mengandung sebuah antikoagulan heparin sodium kering atau asam disodium etilen diaminotetrasetik (EDTA). Sampel darah disimpan selama beberapa hari sbelum dianalisis jika disimpan dalam suhu dngin $\left(4^{\circ} \mathrm{C}\right)$ dan dalam keadaan gelap. Pencampuran darah yang lengkap harus dilakukan jika karbonmonoksida dan hemoglobin ingin diukur terpisah. Hemoglobin total dapat ditentukan dengan mudah melalui konversi menjadi Cyanmethemoglobin yang kemudian ditentukan secara Spektrofometri

\section{Faktor yang ada hubungannya dengan kadar COHb Pekerja parkir plaza x Surabaya Selatan}

Hubungan jenis kelamin, Masa kerja, Umur, Posisi tubuh saat bekerja, kebiasaan merokok, Golongan darah, status gizi, $\mathrm{Hb}$ terhadap kadar $\mathrm{COHb}$ dalam darah petugas parkir plaza x Surabaya.

Menganalisa hubungan $\mathrm{COHb}$ dengan umur, masa kerja, $\mathrm{Hb}$, menggunakan korelasi person karena distribusinya normal sedangkan jenis kelamin, posisi tubuh saat bekerja, merokok menggunakan uji $T$ sampel bebas karena membedakan dua kelompok. Untuk Golongan darah menggunakan analisis varian/anova karena terdapat 4 kelompok. status gizi dengan menggunakan Korelasi spearmans. Dari sini dapat diketahui dapat diketahui bahwa hipotesis dari penelitian telah diterima jika memang ada hubungan antara :

\section{Jenis kelamin}

Berdasarkan kadar $\mathrm{COHb}$ sebelum bekerja, sesudah bekerja dan selisih $\mathrm{COHb}$ pada laki laki lebih tinggi dibanding dengan pada perempuan (uji t 2 sampel bebas; $\mathrm{p}<0.001 ; \mathrm{p}<0.001 ; \mathrm{p}=0.029)$, dimungkinkan akibat paparan CO lingkungan bekerja ditambah riwayat merokok sehingga mempengaruhi kemampuan vital paru dan kebutuhan oksigen seseorang sehingga mempengaruhi kadar $\mathrm{COHb}$, berbanding lurus dengan hasil penelitian Rachmawati (2013) melakukan analisis pengaruh emisi udara pada sentra pengolahan batu kapur terhadap gangguan fungsi paru pekerja dan masyarakat di Desa Karas Kecamatan Sedan Kabupaten Rembang, hasil penelitian menunjukkan adanya pengaruh antara udara lingkungan kerja terhadap gangguan fungsi paru pada masyarakat sentra pengolahan batu kapur di Desa Karas untuk parameter debu dan gas $\mathrm{CO}$, sedangkan $\mathrm{NO}_{2}$ dan $\mathrm{SO}_{2}$ tidak mempengaruhi gangguan fungsi paru.

\section{Umur}

Dibahwa pada petugas parkir yang rata-rata berumur 25,3 tahun menunjukkan bahwa tidak ada hubungan antara umur dengan kadar $\mathrm{COHb}(\mathrm{p}>0,05)$ 
0,673 Umur salah satu faktor kerentanan individu, Secara teoritis umur berbanding lurus dengan kadar $\mathrm{COHb}$ dalam darah, karena sifat elastis paru-paru tidak berubah pada usia 7-39 tahun, tetapi kecenderungan menurun setelah usia 40 tahun. hal ini perlu diperhitungkan peneliti kadar $\mathrm{CO}$ karena semakin tua, seseorang akan semakin rentan terhadap paparan $\mathrm{CO}$, sehingga kadar $\mathrm{COHb}$ nya akan semakin tinggi (Siswanto, 2008).

\section{Masa kerja}

Pekerja yang masa kerjanya rata-rata 2,2 tahun (range $1-7$ tahun) dalam penelitian ini menunjukkan tidak ada hubungan antara masa kerja dengan kadar $\mathrm{COHb}$ sebelum, sesudah bekerja dan selisih $\mathrm{COHb}(\mathrm{p}>0,05)$. Secara teoritis masa kerja berbanding lurus dengan kadar $\mathrm{COHb}$ dalam darah, (Menurut ILO (1983), Pemaparan yang berulang ulang pada kadar sedang mungkin dapat menimbulkan adapatasi. Mekanisme adaptasi hampir sama dengan mekanisme terjadinya toleransi terhadap hipoksia yang tinggi. Sehingga pekerja yang masa kerjanya masih berkisar kurang dari 3 tahun kemungkinan belum mengalami proses adaptasi. Secara teoritis masa kerja berbanding lurus dengan kadar $\mathrm{COHb}$ dalam darah, hal ini dimungkinkan terjadinya kesiapan fisik.

4. $\mathrm{Hb}$ (Hemoglobin)

Uji korelasi Pearson menunjukkan adanya hubungan antara kadar $\mathrm{Hb}$ pekerja dengan kadar $\mathrm{COHb}$ dalam darah ( $\mathrm{p}<0,001 ; \mathrm{p}<0,001 ; \mathrm{p}=0.014)$. Secara teoristis $\mathrm{Hb}$ berbanding lurus dengan kadar $\mathrm{COHb}$ dalam darah karena karbon monoksids (CO) dapat menggeser oksigen yang terikat pada hemoglobin dan mengikat hemoglobin menjadi karboksihemoglobin. Hal ini disebabkan oleh afinitas karbon monoksida terhadap hemoglobin 240 kali lebih kuat dari pada afinitas oksigen terhadap hemoglobin (Slamet, 1996). Jadi CO cenderung berikatan dengan hemoglobin dalam jangka waktu lama (Saladin, 2004). Karboksihemoglobin tidak mampu membawa oksigen sehingga suplai oksigen jaringan terganggu (Moya et al.,1985). Sehingga $\mathrm{Hb}$ ada Transport CO sehingga jika kadar $\mathrm{Hb}$ dalam darah banyak maka, Kemampuan $\mathrm{CO}$ mengikat lebih besar.

\section{Posisi Tubuh saat bekerja}

Hasil uji komparasi menunjukkan bahwa tidak ada beda kadar $\mathrm{COHb}$ antara pekerja yang melakukan pekerjaan dengan berdiri dengan yang duduk $(p>0,05)$. Hal ini dikarenakan berat jenis CO lebih ringan dari Udara vapor density $=0,97$ (Siswanto, 1994). Dengan berat jenis yang lebih ringan dari pada udara, maka gas buang $\mathrm{CO}$ yang keluar dari knalpot, selain knalpot sumber gas $\mathrm{CO}$, berat jenis $\mathrm{CO}$ tidak terlalu berbeda dengan berat jenis udara maka ketinggian pada pekerja duduk dan berdiri mendapatkan paparan $\mathrm{CO}$ yang sama.

\section{Kebiasaan Merokok}

Karena setiap kepulan asap rokok mengandung CO sebanyak 700-800 ppm (Siswanto, 1994). Hasil uji t 2 sampel bebas menunjukkan bahwa kadar $\mathrm{COHb}$ perokok lebih tinggi $0,3 \%$ secara signifikan baik $\mathrm{COHb}$, dibanding dengan pekerja yang bukan perokok $0,1 \%$. Kadar $\mathrm{COHb}$ Sebelum bekerja 9,5\% pada merokok dan 7,5\% tidak merokok ( $\mathrm{p}=$ $0,002)$

$(\mathrm{r}<\alpha)$ sehingga ada hubungan kadar $\mathrm{COHb}$ dengan kebiasaan merokok.

Bila dalam suatu ruangan ada orang yang merokok, akan menyebabkan konsentrasi gas CO pada ruangan tersebut naik. Orang yang merokok akan mengeluarkan asap rokok yang mengandung gas $\mathrm{CO}$ dengan konsentrasi yang tinggi. Konsentrasi gas $\mathrm{CO}$ yang tinggi di salam asap rokok menyebabkan kandungan $\mathrm{COHb}$ dalam darah orang merokok jadi meningkat. Keadaan ini tentu sangat membahayakan bagi kesehatan orang merokok. Orang yang merokok dalam waktu yang cukup lama (perokok berat) konsentrasi $\mathrm{COHb}$ nya dalam darah sekitar 6,9\%. Hal ini yang menyebabkan perokok berat mudah terkenan jantung. Orang yang tidak merokok akan tetapi berada dalam ruangan yang sama dengan orang yang merokok memiliki resiko yang sama dengan orang yang merokok, karena tanpa disadari orang yang tidak merokok tersebut menghirup udara yang tercemari asap rokok, sehingga meningkatkan kadar $\mathrm{COHb}$ dalam darah pula ( Chaeruddin, 2006).

Asap rokok mengandung sekitar 4.000 bahan kimia yang terbagi menjadi dua komponen, yaitu gas phase (Komponen gas) dan particulate phase (Komponen padat atau partikel) (Golding, 1995). Komponen padat yang terpenting yaitu tar merupakan bahan karsinogen dan nikotin, bahan adiktif penyebab ketergantungan atau kecanduan (Aditama, 2001), sedangkan karbon monoksida paling berbahaya diantara komponen gas lainnya karena merupakan penyebab penyakit kardiovaskuler akibat hipoksemia yang ditimbulkan (Golding,1995). 


\section{Golongan darah}

Menurut Rhesus Isoimmunization : increased hemolysis during early 716-712 (1994) Golongan darah adalah hasil dari pengelompokan darah berdasarkan ada atau tidaknya substansi antigen pada permukaan sel darah merah (eritrosit). Eritrosit merupakan bagian utama dari sel-sel darah. Setiap mm kubiknya darah pada seorang laki-laki dewasa mengandung kira-kira 5 juta sel darah merah dan pada seorang perempuan dewasa kira-kira 4 juta sel darah merah, terdapat perbedaan protein jenis dan karbohidrat pada permukaan membrane sel darah merah.

Tiap-tiap sel darah merah mengandung 200 juta molekul hemoglobin. Hemoglobin ( $\mathrm{Hb}$ ) merupakan suatu protein yang mengandung senyawa besi hemin. $\mathrm{CO}$ mengikat reversible ke $\mathrm{Hb}$ dalam sirkulasi eritrosit untuk membentuk $\mathrm{COHb}$ meskipun degradasi protein heme yang lain juga berkontribusi terhadap endogen $\mathrm{CO}$ dan bilirubin produksi, sumber ini menyumbang kurang dari $25 \%$.Untuk memperdalam apakah ada hubungan kadar $\mathrm{COHb}$ dalam darah petugas parkir plaza $\mathrm{x}$ surabaya digunakan Anova dapat diketahui bahwatidak ada beda kadar $\mathrm{COHb}$ pada pekerja dengan golongan darah $\mathrm{A}, \mathrm{B}, \mathrm{AB}, \mathrm{O}(\mathrm{p}>0,05)$ baik kadar $\mathrm{COHb}$ sebelum, sesudah dan selisih $\mathrm{COHb}$

\section{Status gizi (IMT)}

Supariasa, (2002). Menjaga asupan gizi dengan melengkapi kebutuhan tubuh, yakni mengkonsumsi empat sehat lima sempurna, karena kadar $\mathrm{COHb}$ dipengaruhi asupan gizi dalam tubuh seperti besi, tembaga, piridoksin dan lain-lain. Gizi merupakan faktor yang mempengaruhi absorpsi CO oleh tubuh. Keadaan kurang gizi akan meningkatkan kadar $\mathrm{COHb}$ dalam darah.

Hasil uji statistic Anova menunjukkan bahwa tidak ada beda kadar $\mathrm{COHb}$ antara pekerja dengan indeks masa tubuh (IMT) kurus, normal dan gemuk, baik $\mathrm{COHb}$ sebelum, sesudah maupun selisih $\mathrm{COHb}$ $(\mathrm{p}>0,05)$.

\section{KESIMPULAN}

1. Karakteristik Responden petugas parkir plaza $\mathrm{x}$ di 4 lantai yang berjumlah 30 orang, 73\% adalah laki laki dan dan mayoritas berumur kurang dari 40 tahun (23,7 $\pm 5,2$ tahun). Responden yang bekerja di lokasi motor sebesar $40 \%$ dan terbiasa bekerja dengan posisi berdiri sebesar $60 \%$. Responden yang mempunyai kebiasaan merokok sebesar $60 \%$ dan sebagian besar IMT responden berada dalam kategori normal $(63,3 \%)$. Responden mempunyai golongan darah terbanyak adalah $\mathrm{O}$ dan $\mathrm{B}$, dan sebagian dari mereka mengalami anemia (20\%).

2. Hasil penelitian dapat kadar rata-rata $\mathrm{CO}$ lingkungan di seluruh lokasi parkir plaza x sebesar $8,7 \pm 6,4 \mathrm{ppm}$, dengan kadar tertinggi dibagian motor yaitu 16,1 ppm, sedangkan di bagian LG, P1, P2 masing-masing sebesar 4,8,4,6 Jika dibandingkan dengan kadar $\mathrm{CO}$ yang diperkenankan untuk pekerja di dalam ruang (WHO, 1999) sebesar 9 ppm atau Baku Mutu kualitas udara Ambien (PP No 41 tahun 1999) yaitu 10 ppm maka kadar CO di parkir motor sudah melebihi ambang tersebut

3. Uji t 2 sampel bebas menyatakan bahwa kadar $\mathrm{COHb}$ tidak berbeda secara bermakna antara pekerja yang anemia dan normal $(\mathrm{p}=0,77$ untuk $\mathrm{COHb}$ sebelum bekerja ; $\mathrm{p}=0,76$ untuk $\mathrm{COHb}$ sesudah bekerja; $\mathrm{p}=0,73$ untuk selisih $\mathrm{COHb}$ ).

4. Ada perbedaan antara kadar $\mathrm{COHb}$ sebelum bekerja kelompok laki-laki tidak merokok $(8,8 \pm 1,0 \%)$ dibandingkan dengan kadar $\mathrm{COHb}$ perempuan tidak merokok $(6,7 \pm 1,6 \%)$. Setelah bekerja, $\mathrm{COHb}$ kedua kelompok tersebut tetap menunjukkan perbedaan dimana kadar $\mathrm{COHb}$ lakilaki lebih tinggi dibandingkan dengan perempuan

5. Faktor yang ada hubungannya dengan kadar $\mathrm{COHb}$ pada petugas parkir plaza $\mathrm{x}$ adalah jenis kelamin, kebiasaan merokok, kadar $\mathrm{Hb}$, dan kadar CO lingkungan.

\section{Saran}

1. Disarankan kepada Manajemen plaza $\mathrm{x}$ melakukan penambahan local exhaust terutama pada parkir motor untuk pengenceran $\mathrm{CO}$ dari gas buang kendaraan dan asap rokok. Kepada petugas parkir mal yang setiap hari ditempat kerja terpapar oleh gas $\mathrm{CO}$

2. Disarankan pada pekerja parkir agar tidak merokok.

3. Apabila ada petugas Parkir plaza $x$ yang mengalami keracunan berat akibat menghirup gas karbon monoksida pada kadar tinggi sehingga sulit ditangani pada saat itu, segera dibawa ke poliklinik atau rumah sakit terdekat untuk mendapatkan pertolongan lebih lanjut dan intensif, perlu juga dilakukan roling kepada petugas parkir 
4. Disarankan melakukan pemeriksaan kesehatan secara berkala minimal setahun sekali pada pekerja plaza $\mathrm{x}$.

5. Mengingat $\mathrm{COHb}$ melebihi NAB Supaya dilakukan pemantauan, pengawasan dan pengevaluasian secara berkala tentang konsentrasi CO di udara tempat parkir plaza x Surabaya

6. Disarankan mengkomsumsi vitamin c dan e bagi pekerja parkir plaza $\mathrm{x}$.

\section{DAFTAR PUSTAKA}

Admin, (2008). Polusi Udara. http://www.wikipedia.org. (sitasi 6 April 2013).

Anies, (2006). Simpul-simpul Biomonitoring: Manajemen lingkungan, Jakarta EGC.

Anonim, (2008). Carbon Monoxide Available from :http://www.wikipedia.com. (Sitasi 5 April 2013).

Anonim.,(2006), Karbon Monoksida Berbahaya Bagi Jantung. Vol.5 No.8, hal 72.

Anonim.,(2008), Air Pollution. http://www.wikipedia.org/wiki/Airpollution.(Sitasi 18 Juni 2010).

Anonim.,(2009). Carboxyhemoglobin. http://www.wikipedia.org.(Sitasi 5 Maret 2013).

Arikunto, S.,(2006). Prosedur Penelitian. Rineka Cipta.Jakarta, Hal. 130.

Badan Standar Nasional.,(2005). SNI 19-0232-2005 : Nilai Ambang Batas (NAB) Zat

Biologicals. Twelfth Edition. Merck \& Co.,Inc. New Jersey. 1996. p. 296

Bokonjic, (1963). Ekologi dan Kesehatan II, Cermin Dunia Kedokteran. Jakarta.

Budiyono,A.(2009). Waspadai CO Ditempat Parkir Tertutup .http://newspaper pikiran Carbon Monoxide. (Sitasi 2 Juli 2010).

Depkes.RI.(2008).Parameter Pencemaran Udara Terhadap Kesehatan http // www. depkes .go.id/download/udara. pdf. (sitasi 2 Februari 2013)

Ekasatya N, 1991 Pencegahan dan Penanggulangan Pencemaran Lingkungan. Jakarta.FKUI

Fardiaz, Srikandi., (1992). Polusi Air dan udara. Yogyakarta: Kanisius, hal 94-102

FKM Unair., (2013). Panduan Penulisan Usulan Penelitian dan Tesis. Program Magister FKM Unair Surabaya.

Ganong, W.F.,(1990). Fisiologis kedokteran, Edisi $10^{\text {th }}$.ed., AlihBahasa, Adjie Dharma Jakarta : EGC Penerbit Buku Kedokteran.
Guyton, Arthur.C.1993. Fisiologi Manusia dan Mekanisme Terhadap Penyakit EGC.

H.J. Mukono,(1992), Pencemaran udara dan Pengaruhnya terhadap gangguan saluran pernafasan. Surabaya : Airlangga University Press, hal 18-19

H.J. Mukono,(2010), Prinsip dasar kesehatan lingkungan. Airlangga university Press : Surabaya.

Haanen. C. Kunst. Va. Jm. Wagener. Dj Th Burhouts J. Pengantar Ilmu Penyakit.

Handayani, M..(2004). Keracunan yang disebabkan Gas Karbon Monoksida. Info POM

Harian Kompas. Madu dan Racun Bensin Bertimbal. 7 November 1996.

Jamal, Sarjaini.(1992). Pengaruh Rokok Terhadap Kesehatan. Majalah Cermin Dunia Farmasi, No.11.

Joseph M, Patula (1989). The Object of Environmental Ethics, dalam Environmental kesehatan Pekerja. PPS Hiperkes Medis. Fakultas Kedokteran Airlangga University Press : Surabaya.

Kimia di udara Tempat Kerja.Jakarta: Badan Standardisasi Nasional, hal.1 lingkungan Hidup, Seminar Nasional Metode Analisa Kimia, Bandung.

Marji. 1999. Penggunaan saluran Gas Buang untuk mereduksi Karbon Monoksida. Edisi 12. Jakarta EGC.

Nita..(2007). Merokok Pasif Bisa Lebih Bebahaya Dari Pada Merokok Aktif. http://www.majalah-farmacia.com.(sitasi 09 maret 2010)

Nomi, Toshitaka. 2009. Membaca Karaktek Melalui Golongan Darah. Gramedia: Jakarta

Occupational Safety and Heatlh Organization, (2002) Carbon Monoxyde Poisoning, U.S. Departement of Labor, available from : http://www.osha.gov

Oke zone,(2007). Keracunan Karbon monoksida. http://www.google.co.id. (Sitasi 15 Juni 2013 )

Pearce, Evelyn. (2000). Anatomi dan Fisiologi untuk Paramedis. PT Gramedia Pustaka Utama. Jakarta

Prabu.,(2008). Karbon Monoksida (CO). http :/www.Putraprabu.wordpress. com .(sitasi 14 Februari 2010)

Pudjiastuti, $\quad$ L.,Rendra,S.,Santoso,H.,(1998). Kualitas Udara Ruang.Jakarta: Direktorat Jenderal pendidikan Tinggi departemen Pendidikan Dan Kebudayaan, hal 19. 
Sadikin, M. 2002. Biokimia Darah. Widya Medika. Jakarta. p. 12-24

Saeni (1989), Kimia Lingkungan, PAU-IPB Bogor. Saputra, Yoky Edi., (2009). Karbon monoksida dan Dampaknya Terhadap Kesehatan. http://www.chem-is-try.org. (sitasi 05 maret 2010).

Siswanto, A, (1990), Karbon Monoksida. Hiperkes dan Keselamatan Kerja Jawa Timur, hal 383441

Siswanto, A, (1991), Toksikologi Industri, Balai Hiperkes dan Keselamatan Kerja Jawa Timur Departemen Tenaga Kerja, hal 12-14

Suardi, Rudi.,(2007). Sistem Manajemen Kesehatan dan Keselamatan Kerja. Jakarta : PPM, hal 79 $-80$

Suharjo, Saputro, ( 2003 ). Rokok vs Kesehatan Publik Refleksi Hari Kesehatan Sedunia 7 April. Republika Online. http://www.Yahoo.com

Suma'mur P.K, (1984), Hygiene Perusahaan dan Kesehatan Kerja,Gunung Agung, Jakarta.

Suma'mur, PK (2009). Higiene Perusahaan dan Kesehatan Kerja (Hiperkes). Jakarta : Sagung Seto,hal 192, 198.

Surat Edaran Menteri Tenaga Kerja dan Transmigrasi No. 01 Tahun 1997. Nilai Ambang Batas Karbon Monoksida, Jakarta

Susanto, (2008). Artikel Risk Assessment dan Upaya Pengembangan Jasa Konsultasi di Bidang Manajemen Risiko. Fraud Audit Task Force (FTAF). BPKB Capacity Building Project.

Suyono Joko dan Caroline Wijaya (1986). Early Detection Of Occupational Disease. WHO : Geneva).
Triana, Eka, (2008 ).Studi Komparasi Kadar Karbon Monoksida (CO) di Udara pada tempat kedatangan dan pemberangkatan Bus di terminal bus Giwangan Yogyakarta. Karya Tulis Ilmiah. Program Studi Diploma III Kesehatan Lingkungan. Purwokerto.

Tugaswati, Tri, A (2009).Emisi Gas Buang Kendaraan Bermotor dan Dampaknya Terhadap Kesehatan, http://www.kpbb.org/download (situasi 17 Februari 2010 ).

Wicaksana, A, dkk (2002). Dampak Keracunan Gas Karbon Monoksida Bagi Kesehatan pekerja. PPS Hiperkes Medis. Fakultas Kedokteran Universitas Indonesia. Jakarta. Cermin Dunia Kedokteran No. 136

Wijetilleke dan karunaratne, (1995). Prediksi Konsentrasi $\mathrm{COHb}$ yang terikat dalam darah dilihat dari jenis pekerjaannya. Jakarta. EGC.

Wisaksono, W dkk (1981), Peranan Analisa Kimia Dalam Menunjang Masalah Kesehatan.Jakarta : ITB, hal 148.

World Health Organization, (1979). Enviromental Health Criterial3, Carbon Monoxide, Genewa: $35-43$.

World Health Organization, (1999). Enviromental Health Criteria 213, Carbon Monoxide (Second Edition ), Genewa : $30-43$

Yasin, U, 2006). Udara Bersih Semakin Mahal, http://www.yayasan-lembak .blogspot.com. ( situasi 16 April 2010 ). 